\title{
Coronary artery bypass graft angioplasty conducted by 64-slice spiral computed tomography
}

Nieinwazyjne badanie angiograficzne metodą 64-rzędowej tomografii komputerowej wystarczającą podstawą do kwalifikacji pacjentów do zabiegów angioplastyki pomostów aortalno-wieńcowych

\author{
Andrzej Ochała, Marcin Syzdół, Paweł Wieja, Piotr Garbocz, Maciej Sosnowski, Wiesław Cybulski \\ III Department of Cardiology, Medical University of Silesia, Katowice, Poland
}

Post Kardiol Interw 2011; 7, 3 (25): 193-198 DOI: $10.5114 /$ pwki.2011.24734

\begin{abstract}
Background: Multislice spiral computed tomography (MSCT) is an alternative diagnostic method for coronary artery bypasses (CABG) that could enable us to perform graft percutaneous coronary intervention ( $\mathrm{PCI}$ ) almost without angiography.

Aim: The aim was to investigate the efficiency of MSCT in testing the permeability of coronary artery bypasses and possible constriction in the group of symptomatic patients in class CCS II or greater. The other aim of this study was to compare the non-invasive method (MSCT) with the invasive one (angiography) and to determine its sensitivity, specificity and diagnostic accuracy.

Material and methods: Fifty-eight symptomatic patients after CABG were involved in the study. We analysed 128 bypass grafts (32 arterial and 96 vein). In this group in 17 patients (43.5\% of cases) we had to perform $\mathrm{PCl}$ of the graft or the native coronary artery.

Results: Nine occluded and 2 constricted arterial coronary bypasses were found and 16 occluded, 6 constricted vein coronary bypasses in MSCT. In conventional coronarography used as the reference method 7 occluded, 2 constricted arterial coronary bypasses and 17 occluded, 5 constricted vein coronary bypasses were confirmed. The sensitivity and specificity of MSCT were very high. The time of the procedure, amount of contrast and dose of radiation were significantly higher during PCI based on the traditional bypass angiography.

Conclusions: The PCI of grafts based only on 64-slice MSCT is safe and the sensitivity, specificity and accuracy of this diagnostic method are very high. The procedure based on non-invasive qualification significantly decreased the amount of contrast and fluoroscopy.
\end{abstract}

Key words: cardiac computed tomography, coronary artery bypass grafts

\section{Streszczenie}

Wstęp: Wielorzędowa tomografia komputerowa (ang. multislice spiral computed tomography, MSCT) stanowi obiecującą alternatywę, umożliwiającą wiarygodną ocenę stanu pomostów aortalno-wieńcowych.

Cel: Analiza skuteczności 64-rzędowej MSCT w ocenie drożności wszczepionych pomostów aortalno-wieńcowych oraz ewentualnych zwężeń w miejscu wszycia pomostu do naczynia wieńcowego u chorych z objawami dławicy piersiowej po pomostowaniu aortalno-wieńcowym (ang. coronary artery bypasses, CABG) oraz bezpośrednie porównanie metody nieinwazyjnej (MSCT) z inwazyjną i określenie jej czułości, specyficzności i dokładności diagnostycznej.

Materiał i metody: Do analizy włączono 40 pacjentów po zabiegu CABG z dolegliwościami dławicowymi CCS II i wyżej. Analizie poddano łącznie 128 pomostów, w tym 32 zespolenia tętnicze i 96 pomostów żylnych. Spośród przebadanych chorych w 17 przypadkach (42,5\%) wykonano zabiegi przezskórnej interwencji wieńcowej (ang. percutaneous coronary intervention, PCI) dotyczące pomostów aortalno-wieńcowych lub tętnic natywnych.

Wyniki: W badaniu MSCT uwidoczniono 9 zamkniętych i 2 zwężone pomosty tętnicze oraz 16 zamkniętych i 6 zwężonych graftów żylnych. W konwencjonalnej angiografii potwierdzono obecność 7 zamkniętych i 2 zwężonych pomostów tętniczych oraz 17 zamkniętych i 5 zwężonych pomostów żylnych. Czułość, specyficzność metody, a także dokładność diagnostyczna były bardzo duże. W uzyskanych wynikach czas trwania zabiegu, ilość zużytego kontrastu oraz dawka promieniowania były istotnie większe w przypadku zabiegu angioplastyki wykonanego metodą tradycyjnej angiografii.

Wnioski: Wykonanie zabiegu angioplastyki pomostu aortalno-wieńcowego opartego tylko na wyniku 64-rzędowej tomografii komputerowej jest bezpieczne dla pacjenta, a biorąc pod uwagę dużą czułość, specyficzność i dokładność diagnostyczną tej metody, które wykazano w badaniu, możliwość nieprawidłowego kwalifikowania pacjenta jest bardzo mała.

Słowa kluczowe: tomografia komputerowa, pomosty aortalno-wieńcowe

Corresponding author/Adres do korespondencji:

Andrzej Ochała MD, PhD, III Department of Cardiology, Medical University of Silesia, 47 Ziołowa, 40-635 Katowice, Poland, tel./fax: +48 32 252 3930 , e-mail: aochała@poczta.onet.pl

Praca wpłynęła 4.07.2011, przyjęta do druku: 30.08.2011. 


\section{Introduction}

The growing number of patients undergoing surgical myocardial revascularization and difficulties in objective assessment of coronary artery disease progression in this group of patients require an efficient and non-invasive method of systematic evaluation of implanted grafts. Approximately $10 \%$ of the implanted grafts undergo occlusion in the early postoperative period. Over half of venous bypasses and $17 \%$ of arterial bypasses degenerate during the following 10 years [1, 2]. Patients after coronary artery bypass grafting (CABG) who have many risk factors of coronary artery disease (such as diabetes or hypertension) quite often present with non-characteristic symptoms, which are not always caused by deficits in myocardial perfusion. On the other hand, commonly used non-invasive methods such as echocardiography or exercise electrocardiogram (ECG) testing are characterized by a high proportion of false positive results in this group of patients [3]. Besides, none of the above examinations provide reliable information whether the cause of ischaemia is related to failure of a certain graft and therefore the main question remains unanswered: is it necessary to continue the diagnostic process and to perform a revascularization procedure? Gold-standard methods indicated at this point consist of coronary angiography and by-passography. However, these examinations cannot be considered as screening methods due to their invasive nature, long time of procedures or difficulties in the their execution frequently found in this group of patients. Multislice computed tomography (MSCT, angio (T) - one of the fastest developing branches of radiology - may be a promising alternative $[4,5]$. This method also has some limitations. An example of those is the presence of artefacts related to arrhythmia, tachycardia or insufficient expertise of the medical personnel. Dynamic technical progress including introduction of 64-, 128- or even 329-slice scanners, construction of dual source scanners or limitation of time necessary to acquire data obtained using sequential mode computed tomography will probably minimize the limitations of the study in the near future. At this point the usefulness of angio CT in the assessment of coronary artery bypass patency or stenosis in the site of anastomosis is a class II B recommendation (level of evidence C). Analysis of coronary artery grafts using 64-slice CT may be a reliable and sufficient method for the assessment of implanted grafts. It may help to make a correct decision about the future therapeutic management including the necessity to perform a revascularization procedure $[6,7]$

\section{Aim}

The aim of the study was:

1) to assess the efficacy of 64-slice angio $C T$ in the evaluation of implanted coronary artery graft patency and stenosis in the site of anastomosis between the graft and the native artery in patients with symptoms of angina after CABG;

2) to directly compare a non-invasive method (angio CT) to the invasive examination and to assess its sensitivity, specificity, diagnostic accuracy and the amount of contrast and radiation dose required;

3) to evaluate the possibility of patient qualification for percutaneous coronary intervention of the graft based on the 64-slice MSCT.

\section{Material and methods}

The analysis included patients after surgical myocardial revascularization with symptoms of stable coronary artery disease (class II and higher) who had been qualified for invasive diagnostics of the heart. Between March 2008 and March 2009 a total of 58 patients were included (all patients hospitalized in that period who met the inclusion criteria - signed an informed consent form for participation in the study, had CCS class II or higher symptoms, were qualified for the invasive diagnostics of the heart and who did not meet the exclusion criteria - arterial fibrillation, allergy to the contrast agent, renal failure). In 18 patients angio CT had not been performed mainly due to arrhythmia and tachycardia persisting despite pharmacotherapy. All other patients underwent angio CT followed by coronary angiography/by-passography. The study had the approval of the Bioethical Committee of the Silesian Medical University in Katowice.

Mean time between CABG and angio-CT was $7.3 \pm 2.4$ years. Eight patients received venous grafts, 4 patients had arterial grafts (LIMA-LAD) and all other patients had venous and arterial grafts (70\%). There were no jump grafts or Y-grafts implanted in the studied group. A total of 128 grafts were analysed including 32 arterial bypasses and 96 venous bypasses. Percutaneous coronary intervention $(\mathrm{PCI})$ of the aorto-coronary bypasses or native arteries was performed in 17 patients (42.5\%) in the studied group.

Study group characteristics are presented in table 1.

\section{Multislice computed tomography}

Angio CT studies were performed using a 64-slice scanner (Toshiba Aquilion) with rotational speed of $150 / \mathrm{min}$, slice thickness of $0.5 \mathrm{~mm}$, voltage $120-135 \mathrm{kV}$. Patients received $120 \mathrm{ml}$ of contrast agent (Iomeron 400) with a speed of 3.5-5 ml/s depending on the maximal size of the installed venous access. Synchronization between the acquisition and contrast administration was based on monitoring of the radiation intake in the descending aorta at the level or trachea bifurcation. The field of view was adjusted to the type of analysed grafts and increased cranially in the case of arterial grafts. Radiation dose was 1318-3194 mGy/cm (mean radiation dose 2100.2 $\pm 417.3 \mathrm{mGy} / \mathrm{cm})$.

Patients with a mean heart rate over $65 / \mathrm{min}$ received $50 \mathrm{mg}$ of metoprolol p.o. or 2.5 to $5 \mathrm{mg}$ of metoprolol i.v. 
directly before the study. In the case of persisting heart rate over 70/min the study was cancelled (in 6 patients it was postponed and was eventually successful in 4 patients from that group at a different time). Each patient received $0.6 \mathrm{mg}$ of NTG p.o. directly before the study.

Analysis included 2D (MPR, CMRP, MIP) and 3D (VRT) image reconstructions which were obtained in the enddiastolic phase. There were no complications observed during the examination.

Analysis included aorto-coronary grafts and anastomoses. Assessment was performed by a team of a radiologist and a cardiologist and included graft patency and the presence or absence of significant lesions (significant lesion was defined as stenosis between 60\% and 99\%). Degree of stenosis was assessed by comparison of the graft diameter in the site of stenosis to its diameter in the non-stenosed part located proximally to the site of stenosis. The analysis also included the presence of stents, clips, etc., which could influence the results of angio CT.

\section{Aorto-coronary graft angiography}

Mean time between MSCT and by-passography was 1.5 days $( \pm 1.3)$. Studies were performed according to the accepted recommendations. Angiography was done by a cardiologist who assessed the degree of graft stenoses using the QCA method. The same criteria for significant stenosis as in MSCT were applied.

\section{Percutaneous transluminal angioplasty of the} aorto-coronary grafts

The result of the MSCT study was used to initially qualify the stenosis in the graft for $\mathrm{PCl}$. Apart from the degree of stenosis, additional information obtained consisted of lesion characteristics and its length. A final decision about the $\mathrm{PCl}$ was made after the assessment of angiograms, which permitted analysis of the influence of angiography on the initial decision.

\section{Statistical analysis}

Parametric data were presented as means and standard deviations or as medians and interquartile ranges (in the case of abnormal distribution). Non-parametric data were presented as absolute values and percentages. Sensitivity, specificity, positive predictive value (PPV) and negative predictive value (NPV) were calculated to compare the efficacy of 64-slice angio CT in the assessment of the aorto-coronary graft patency. Diagnostic accuracy of MSCT in the detection of abnormal grafts in comparison to traditional angiography as the reference method was calculated as follows: [the number of positive results + the number of negative results)/the number of all grafts]. A graft was defined as abnormal in the case of its occlusion or if at least one segment of the graft or the site of anastomosis with the native artery was significantly
Table 1. Characteristics of the analysed population $(n=40)$

Tabela 1. Charakterystyka badanej populacji $(n=40)$

\begin{tabular}{lc} 
Male sex & $34(85 \%)$ \\
\hline Age [years] & $64 \pm 7.0$ \\
\hline Hypertension & $36(90 \%)$ \\
\hline Dyslipidaemia & $31(77.5 \%)$ \\
\hline Diabetes & $13(32.5 \%)$ \\
\hline Family history & $16(40 \%)$ \\
\hline Smoking & $27(67.5 \%)$ \\
\hline Previous myocardial infarction & $20(50 \%)$ \\
\hline Previous stroke or TIA & $4(10 \%)$ \\
\hline Previous PCl & $10(25 \%)$ \\
\hline Graft characteristics & $28(70 \%)$ \\
\hline Arterio-venous grafts & $4(10 \%)$ \\
\hline Arterial grafts only & $8(20 \%)$ \\
\hline Venous grafts only & $4(10 \%)$ \\
\hline One graft & $7(17.5 \%)$ \\
\hline Two grafts & $17(42.5 \%)$ \\
\hline Three grafts & $12(30 \%)$ \\
\hline More than three grafts & $60.9 \pm 5.47$ \\
\hline Angio CT study: & $27(67.5 \%)$ \\
\hline Heart rate &
\end{tabular}

stenosed. Wilcoxon test was used for the comparison between groups. Statistical significance was set at $p<0.05$. Statistical tests were computed using Statistica software.

\section{Results}

The analysis included a total of 128 grafts (32 arterial grafts and 96 venous grafts). The MSCT study detected 9 occluded and 2 stenosed arterial grafts and 16 occluded and 6 stenosed venous grafts. Conventional angiography confirmed the presence of 7 occluded and 2 stenosed arterial grafts and 17 occluded and 5 stenosed venous grafts. Two arterial grafts described in MSCT as occluded were found patent, but both of them were implanted into arteries of a relatively small diameter. Besides, in both cases traditional by-passography demonstrated slow flow of contrast. One of the venous grafts described as stenosed in MSCT was found occluded on angiography. Sensitivity, specificity and diagnostic accuracy were very high. The results are presented in table 2.

The following parameters were theoretically compared in the group of patients who underwent $\mathrm{PCl}$ : time of procedure, amount of contrast agent used, radiation dose during $\mathrm{PCl}$ without preceding graft angiography and with traditional by-passography. The results are presented in table 3. Time of the procedure, the amount of contrast agent used and the radiation dose were significantly higher 
Table 2. Outcomes of coronary artery bypass evaluation in MSCT

Tabela 2. Wyniki oceny pomostów aortalno-wieńcowych metodą MSCT

\begin{tabular}{lccccccccccc} 
& & TP & TN & FP & FN & Sensitivity (\%) & Specificity (\%) & PPV (\%) & NPV (\%) & DD (\%) \\
\hline Occluded grafts: & & & & & & & & & & & \\
\hline All grafts & 128 & 24 & 101 & 2 & 1 & 96 & 98 & 92 & 99 & 98 \\
\hline Arterial grafts & 32 & 7 & 23 & 2 & 0 & 100 & 92 & 78 & 100 & 94 \\
\hline Venous grafts & 96 & 17 & 78 & 0 & 1 & 94 & 100 & 100 & 99 & 99 \\
\hline Stenosed grafts: & & & & & & & & & & & \\
\hline All grafts & 128 & 7 & 120 & 1 & 0 & 100 & 99 & 87.5 & 100 & 99 \\
\hline Arterial grafts & 32 & 2 & 30 & 0 & 0 & 100 & 100 & 100 & 100 & 100 \\
\hline Venous grafts & 96 & 5 & 90 & 1 & 0 & 100 & 99 & 83 & 100 & 99
\end{tabular}

$T P$ - true positive results, $T N$ - true negative results, $F P$ - false positive results, $F N$ - false negative results, $P P V$ - positive predictive value, $N P V$ - negative predictive value, $D D$ - diagnostic accuracy

Table 3. Comparison of $\mathrm{PCl}$ after initial diagnosis made by angio-CT and without prior diagnosis

Tabela 3. Porównanie parametrów zabiegów PCI podjętych po wstępnej diagnostyce angio-CT i bez wstępnej diagnostyki

\begin{tabular}{lccc} 
& $\begin{array}{c}\mathrm{PCl} \text { of grafts after angio CT } \\
\text { without by-passography }\end{array}$ & $\begin{array}{c}\mathrm{PCl} \text { of grafts with } \\
\text { by-passography }\end{array}$ & Value of $p$ \\
\hline $\begin{array}{l}\text { Time of the procedure [min]/total time of invasive diagnostics } \\
\text { and PCl minus time required for by-passography bs. total time } \\
\text { of invasive diagnostics and PCl }\end{array}$ & $38 \pm 5$ & $52 \pm 3.2$ & $<0.05$ \\
\hline The amount of contrast agent [ml] & & & \\
\hline Radiation dose [mGy] & $170 \pm 40$ & $250 \pm 30$ & 0.01 \\
\hline
\end{tabular}

in the case of $\mathrm{PCl}$ performed after traditional bypassography.

Angioplasty of aorto-coronary graft based on the result of 64-slice computed tomography is safer for the patient and the risk of incorrect qualification of patients is very low as demonstrated by high sensitivity, specificity or diagnostic accuracy.

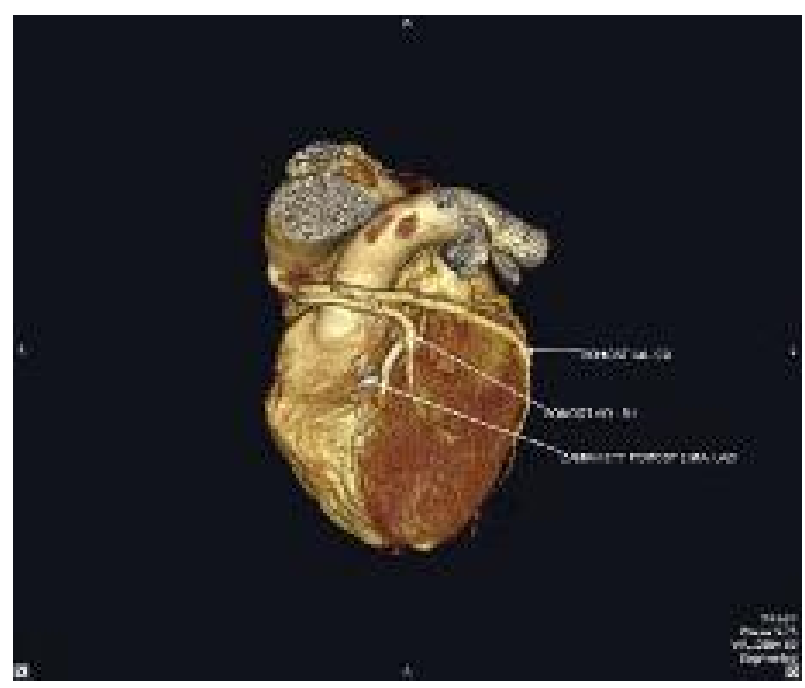

Fig. 1. Occluded coronary graft LIMA-LAD

Ryc. 1. Niedrożny pomost LIMA-LAD

\section{Discussion}

Technological progress observed in the recent years led to the development of the next non-invasive method which can be a useful tool for monitoring the status of aortocoronary grafts. Young-Guk Ko et al. demonstrated high (over 93\%) sensitivity of MSCT in the detection of occluded grafts and $99 \%$ specificity of this method [8]. Even higher

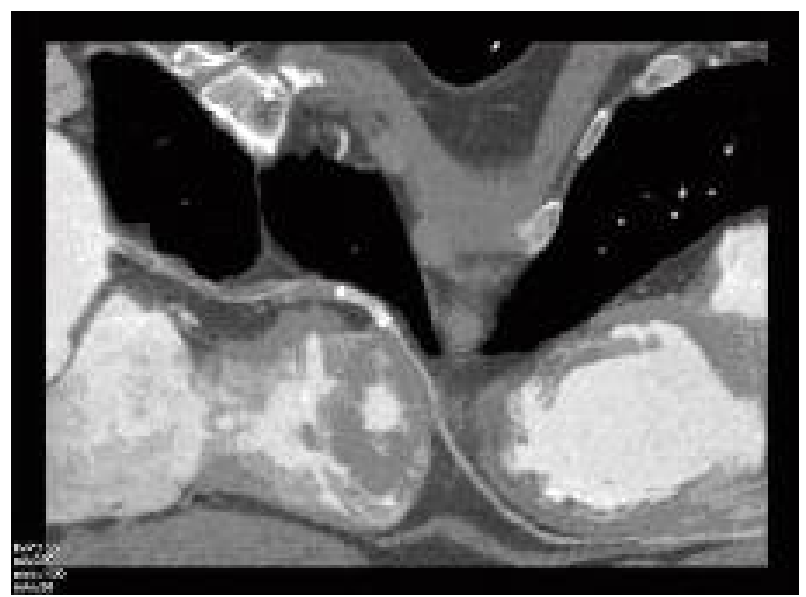

Fig. 2. Occluded vein coronary graft Ao-LAD, occluded stent in the anastomosis

Ryc. 2. Niedrożny pomost Ao- $L A D$, niedrożny stent w miejscu wszycia 


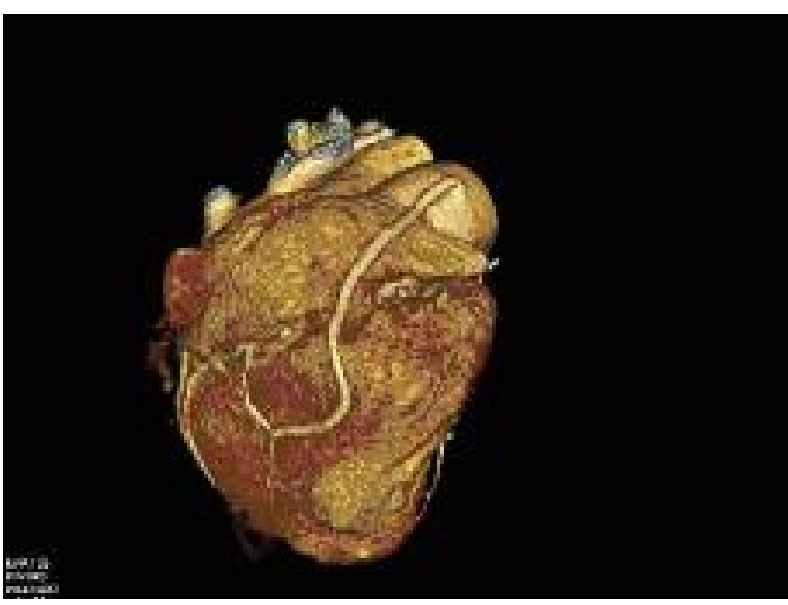

Fig. 3. Normal vein coronary bypass to PDA

Ryc. 3. Prawidłowy pomost żylny wszyty do PDA

sensitivity (100\%) and equally high specificity for the detection of diseased aorto-coronary grafts were reported by Malagutti et al. [9]. Our study proved that 64-slice angio CT has a high diagnostic accuracy and may be used as a first line method for the qualification of patients for angioplasty of aorto-coronary grafts. Metallic clips accompanying arterial bypasses did not influence the sensitivity of this method. The MSCT may be particularly important in patients who do not pay attention to their medical records and in patients after re-CABG. In those situations, the physician performing the intervention faces difficulties in finding the grafts and assessing their number. This is usually related to the administration of higher amounts of contrast agent, prolonged time of the procedure and the use of higher doses of radiation. Additionally, in those situations a risk of graft omission is present. The MSCT does not require selective contrast agent administration and permits the assessment of the number and type of grafts with $100 \%$ sensitivity in comparison to traditional angiography. As demonstrated in our study, it is also possible to analyse graft patency, which can be used by an interventional cardiologist to prepare for directed intervention. This study has obvious limitations. To make a correct decision about the revascularization an assessment of native coronary arteries (except the status of aorto-coronary grafts) is needed. Analysis of native arteries which are massively calcified or after previous $\mathrm{PCl}$ procedures with stent implantation more frequently leads to incorrect results of MSCT in comparison to the assessment of grafts. Results obtained using newer generation scanners significantly reduce this problem.

\section{Conclusions}

The 64-slice computed tomography is a very good noninvasive method permitting a detailed assessment of aorto-coronary grafts. This study permits a precise analysis

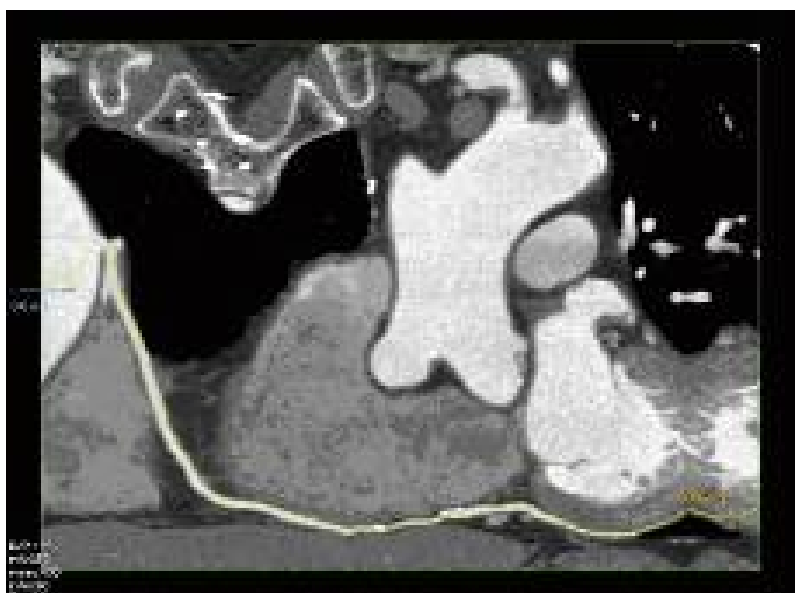

Fig. 4. Normal vein coronary bypass to PDA

Ryc. 4. Prawidłowy pomost żylny wszyty do PDA

of significant graft stenoses or graft occlusions. Because of its non-invasive nature, MSCT should be a method of choice in the graft assessment during regular controls of patients. In our opinion, the use of 64-slice or newer generation scanners helps in decision making regarding the treatment of diseased grafts without the necessity of traditional angiography. The $\mathrm{PCl}$ procedures based on the results of MSCT only are characterized by a shorter duration, lower radiation dose and lower amount of the contrast agent used. Significant problems limiting the use of MSCT in the diagnosis of aorto-coronary grafts still include tachyarrhythmias and other arrhythmias which are frequently present in patients after cardio-surgical procedures. These limitations will probably be eliminated with the continuing technological progress.

\section{References}

1. Gibbon GM, Leach AJ, Kafka HP, Keon WJ. Coronary bypass graft fate: long-term angiographic study. J Am Coll Cardiol 1991; 17: 1075-1080.

2. Bryan AJ, Angelini GD. The biology of saphenous vein graft occlusion: etiology and strategies for prevention. Curr Opin Cardiol 1994; 9: 641-649.

3. Chin AS, Goldman LE, Eisenberg MJ. Functional testing after coronary artery bypass graft surgery: a meta-analysis. Can J Cardiol 2003; 19: 802-8.

4. Doi H, Koshima R, Suzuki M, et al. Can 64-row computed tomography replace angiography after coronary bypass? Asian Cardiovasc Thorac Ann 2008; 16: 444-449.

5. Kępka C, Opolski MP, Kruk M, et al. Dual-source computed tomography angiography in patients after bypass grafting comparison with invasive coronary angiography. Post Kardiol Interw 2010; 6: 12-20.

6. Auguadro C, Manfredi M, Scalise F, et al. Multislice computed tomography for the evaluation of coronary bypass grafts and native coronary arteries: comparison with traditional angiography. J Cardiovasc Med (Hagerstown) 2009; 10: 454-460. 
7. Nazeri I, Shahabi P, Tehrai M, et al. Assessment of patients after coronary artery bypass grafting using 64-slice computed tomography. Am J Cardiol 2009; 103: 667-673.

8. Ko YG, Choi DH, Jang YS, et al. Assessment of coronary artery bypass graft patency by multislice computed tomography. Yonse Med J 2003; 44: 438-444.

9. Malagutti P, Nieman K, Meijboom WB, et al. Use of 64-slice CT in symptomatic patients after coronary bypass surgery: evaluation of grafts and coronary arteries. Eur Heart J 2007; 28: 1879-1885.

10. Bunce $\mathrm{NH}$, Lorenz $\mathrm{CH}$, John AS, et al. Coronary artery bypass graft patency: assessment with true ast imaging with steady-state precession versus gadolinium-enhanced MR angiography. Radiology 2003; 227: 440-446.

11. Hamon M, Lepage $O$, Malagutti $P$, et al. Diagnostic performance of 16- and 64-section spiral CT for coronary artery bypass graft assessment: meta-analysis. Radiology 2008; 247: 679-686.

12. Stanford W, Brundage BH, MacMillan R, et al. Sensitivity and specificity of assessing coronary bypass graft patency with ultrafast computed tomography: results of a multicenter study. J Am Coll Cardiol 1988; 12: 1-7.

13. Engelmann MG, von Smekal A, Knez A, et al. Accuracy of spiral computed tomography for identifying arterial and venous coronary graft patency. Am J Cardiol 1997; 80: 569-574.

14. Ropers D, Pohle FK, Kuettner A, et al. Diagnostic accuracy of noninvasive coronary angiography in patients after bypass surgery using 64-slice spiral computed tomography with 330-ms gantry rotation. Circulation 2006; 114: 2334-2341.

15. Ropers D, Ulzheimer S, Wenkel E, et al. Investigation of aortocoronary artery bypass grafts by multislice spiral computed tomography with electrocardiographic-gated image reconstruction. Am J Cardiol 2001; 88: 792-795.

16. Nieman K, Pattynama PM, Rensing BJ, et al. Evaluation of patients after coronary artery bypass surgery: CT angiographic assessment of grafts and coronary arteries. Radiology 2003; 229: 749-756.

17. Chiurlia E, Menozzi M, Ratti C, et al. Follow-up of coronary artery bypass graft patency by multislice computed tomography. Am J Cardiol 2005; 95: 1094-1097.

18. Salm LP, Bax JJ, Jukema JW, et al. Comprehensive assessment of patients after coronary artery bypass grafting by 16-detector-row computed tomography. Am Heart J 2005; 150: 775-781.

19. Anders K, Baum U, Schmid M, et al. Coronary artery bypass graft (CABG) patency: assessment with high-resolution submillimeter 16-slice multidetector-row computed tomography (MDCT) versus coronary angiography. Eur J Radiol 2006; 57: 336-344.

20. Pache G, Saueressig U, Frydrychowicz A, et al. Initial experience with 64-slice cardiac CT: non-invasive visualization of coronary artery bypass grafts. Eur Heart J 2006; 27: 976-980.

21. Hoffmann MH, Shi H, Schmitz BL, et al. Noninvasive coronary angiography with multislice computed tomography. JAMA 2005; 293: 2471-2478.

22. Leschka S, Husmann L, Desbiolles LM, et al. Optimal image reconstruction intervals for non-invasive coronary angiography with 64-slice CT. Eur Radiol 2006; 16: 1964-1972.

23. Herzog C, Arning-Erb M, Zangos S, et al. Multi-detector row CT coronary angiography: influence of reconstruction technique and the heart rate on image quality. Radiology 2006; 238: 75-86. 